\title{
335 四角筒の曲げ崩壊に関する研究
}

Study on Bending Collapse of Square Tubes

米田裕一（東京理科大） 正 陳 玳珩（東京理科大）学 増田健一（東京理科大） 正 尾崎伸吾（東京理科大）

Hirohito YONEDA, Dai-Heng CHEN, Kenichi Masuda and Shingo OZAKI,

Tokyo University of Science, Kagurazaka 1-3, Shinjuku-ku, Tokyo

Key Words: Buckling, Bending collapse, Square tube, FEM, Deformation behavior

\section{1. 緒言}

一般的な自動車等の衝突現象を省みると, 正面衝突に加え, 斜め力向からの衝突安全性の評価も重要となる.したがって, 衝撃エネルギ一吸収部材として用いられている薄肉角筒の斜め 衝突に伴う軸方向圧潰を受けながらの曲げ崩壊挙動の把握は重 要な課題である. しかし, 円管の曲げ崩壊に関する研究注多数 報告されているが，角筒に関するものは少ない。

本研究では，任意の負荷方向に対するエネルギ一吸収特性 の解明を目的とし，その前段階として，四角筒が曲げモ一メ ントのみを受ける場合の曲げ崩壊特性に注目する。具体的に は, 種々の幾何形状のもと, 角筒の純曲げの弾塑性 FE 解析を 行い, 曲げ挙動を系統的に検討する.

\section{2. 解析方法}

本研究では有限要素法汎用ソルバーMSC. Marc を用いて有 限変形・弾塑性解析を行う. 図 1 に解析に用いる四角筒の幾何 形状を示す.ここで, 一辺の長さ $l=50[\mathrm{~mm}]$, 角筒の長さ $h=600$ $[\mathrm{mm}]$, 肉厚 $t=2[\mathrm{~mm}]$ の正方形角筒を基本モデルとする. また, 材料特性にはミーゼスの降伏条件に従う均質・等方な弾塑性 体を想定し, 一軸応力状態における応力ーひずみ関係は二直線 硬化則に従うものとする. 具体的な材料定数値として, 降伏応 力を $\sigma_{y}=72.4[\mathrm{MPa}]$, 縦弾塑性係数を $E=72.4[\mathrm{GPa}]$, 塑性硬化係 数を $E_{h} / E=0.01$, ポアソン比を $v=0.34$ と設定し, 3 次元シ エル要素を用いて解析を行った。

境界条件は図 1 に示すように四角筒の片方の端部を剛体板 に完全に固定し，他端部にはめくれを防止のための蓋（剛体） を付ける.また，蓋部分に回転変位を与えることで純曲げ条 件を実現している。

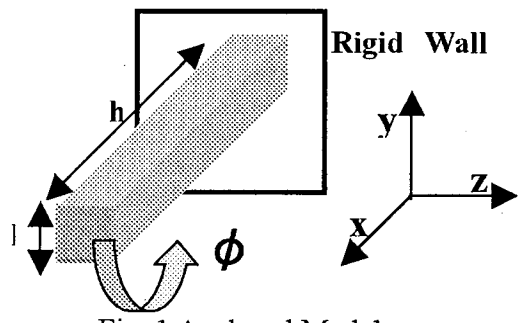

Fig. 1 Analyzed Model.

\section{3. 解析結果及び検討}

3.1 基本モデルを用いた曲げ崩壊特性に関する検討

先ず，基本モデルを用いて，角筒の曲げ崩壊特性について 整理する. 固定端が受ける $\mathrm{z}$ 軸周りのモーメントと回転角 $\theta$ の 関係を図 2 に示す．またその際の回転変位に伴う四角筒の曲 げ形状及び座屈面（図中のA）の断面形状を図 3 に示す。さ らに図 3 の変形形状から明らかになった座屈断面における下 端角部および中央部での $\mathrm{x}$ 軸方向の圧縮応力も併せて図 2 に 示している、これらの図より，正园角筒の基本モデルの変形 形状, 曲げモーメントおよび圧縮応力は次の特徵を有するこ とがわかる。
(1) 回転変位とともに応力は徐々に上昇していくが, 角筒先 端付近の下面中央部に座屈が生じ, これに伴い中央部の 圧縮応力は急激に低下する。

(2) 下面中央部に座屈が生じた後でも，角部には座屈が生じ ず，角部の圧縮応力は上昇する，そのため，曲げモーメ ントは低下するものの, その下降勾配は中央部の圧縮応 力に比べなだらかである。

(3) 角部の応力がある程度大となると, 角部にも座屈が生じ, 応力は下降する。またそのため, モーメントの下降勾配 も大きくなる。

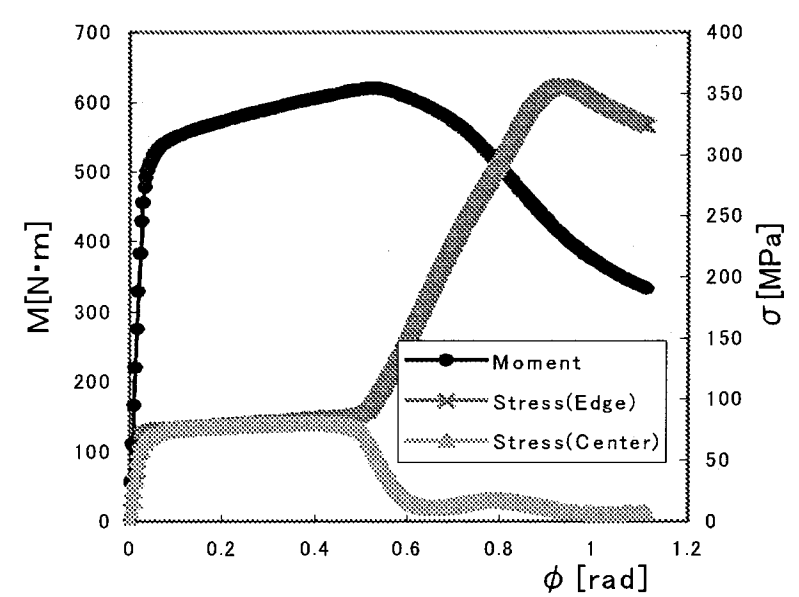

Fig.2 Variations of bending moment and stresses with rotational angle.

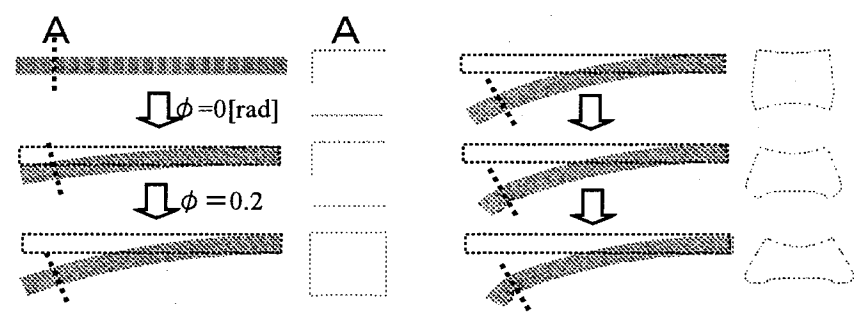

Fig.3 Deformed Shapes of basic model under pure bending.

\section{2 肉厚 $t$ による影響}

角筒の肉厚を $t=1,2,3[\mathrm{~mm}]$ の 3 水準に変化させた場合の $z$ 軸方向に受けるモーメント，座屈面での x 軸方向一の圧縮応 力および回転角 $\phi$ について，基本モデルとの比較を通して， 肉厚 $t$ の曲げ崩壊特性に与える影響について検討する.

図 4 に最大曲げモーメントと肉厚 $t$ の関係を示す。 また, 図 5 には, 最大曲げモーメントおよび下面座屈応力発生時の回転 角 $\phi$ と肉厚 $t$ の関係を示す. なお参考のため, 肉厚 $t=1,3[\mathrm{~mm}]$ の場合における曲げ崩壊時の変形の様子を図 6 に示す。図 4 および 5 より，肉厚 $\mathrm{t}$ とともに最大モーメントおよび座屈応力 
の值は大きくなっており，これに伴い要する回転角度も大き くなっている．また，曲げ変形のメカニズムとしては，前述 の基本モデルと同様に，下面中央部では座屈により応力が急 激に降下するが，角部においてはその後も圧縮応力を受け持 つため，モーメントはピーク後なだらかに減少する。他方， 図 6 に示すように, $t=1[\mathrm{~mm}]$ の場合は基本モデルと同様に角筒 先端付近に座屈断面が形成されるのに対して, $t=3$ [mm]の場 合恃角筒の中央部付近に座屈面 (扁平な断面) が形成される.

このように，角筒の純曲げにお゙いては，肉厚によって $2 つ の$ 変形モードが現れることがわかる。

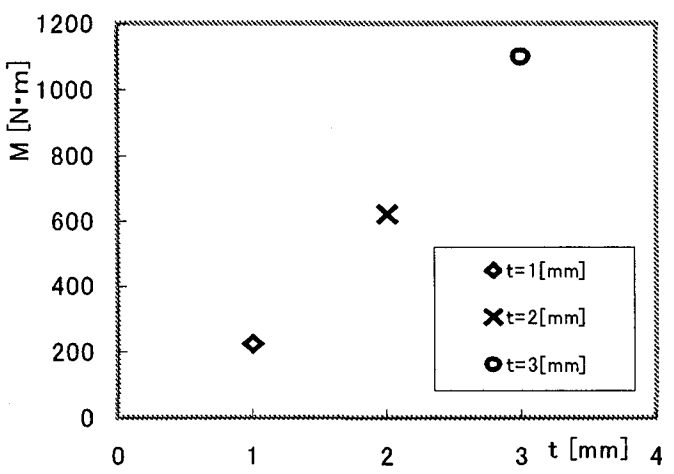

Fig. 4 Relationship between maximum moment and thickness.

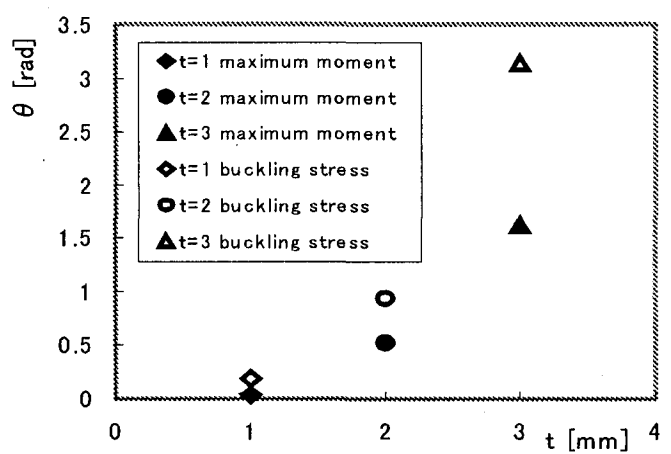

Fig. 5 Relationship between rotational angle and thickness at various state.
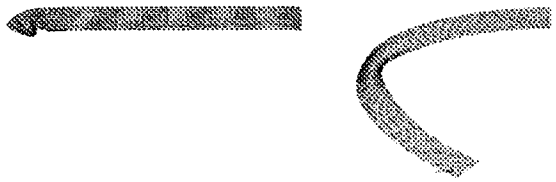

(a) $t=1[\mathrm{~mm}]$

(b) $t=3[\mathrm{~mm}]$

Fig. 6 Deformed Shapes of square tube at the maximum moment.

\section{3 長さ $l$ による影響}

次に，基本モデルをベースに，軸方向長さ $h$ をパラメータ 一として数水準に変化させた場合の角筒の曲げ崩壊特性につ いて検討する。図 7 に, 座屈面角部に生じる最大応力と回転 角度の関係を示す，図より，角筒の曲げ崩壊特性を支配する 要因である座屈面角部の最大忘力は軸方向の長さ $l$ に依存し ないことがわかる。これはどの長さのモデルにおいても座屈 が角筒先端で起きたため，モーメントには影響しなかったた めであると考えられる。

3.4 断面のアスペクト比による影響

断面のアスペクト比による影響を検討するため, 断面形状
をモデル B $(50[\mathrm{~mm}] \times 100[\mathrm{~mm}])$ ，モデル C $(100[\mathrm{~mm}] \times 50$ $[\mathrm{mm}]$ ）と変化させて解析を行い, 基本モデル A（正方形： 50 $[\mathrm{mm}] \times 50[\mathrm{~mm}])$ に対して比較を行う. 図 8 および 9 に，モデ ル B および C の場合における $\mathrm{z}$ 軸周りの曲げモーメント，座 屈断面における圧縮応力と回転角 $\theta$ の関係をそれぞれ示す. これらの図より，モデル B では，曲げ初期において下面部に 座屈が生じるため, 中央部の応力は, ピーク後, 急激に下降 している．他方，モデル C は，モデル B に比べ座屈開始が遅 く, 降伏後もしばらく応力を保つ. また, モ一メント, 各応力 ともにモデル C が, 基本モデルおよびモデル B より大きい值 を示している．これは，x軸に関して断面係数が $\mathrm{B}$ に対して大 きいことの影響だと考えられる。

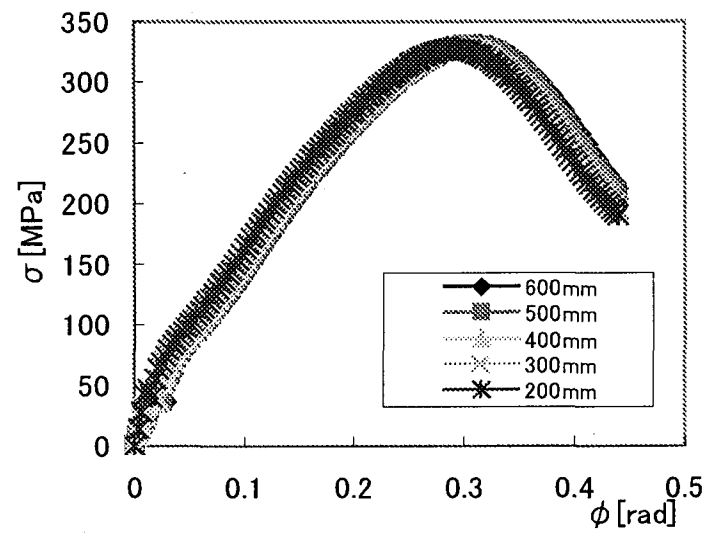

Fig. 7 Variations of stress in the corner of buckling cross-section with rotational angle.

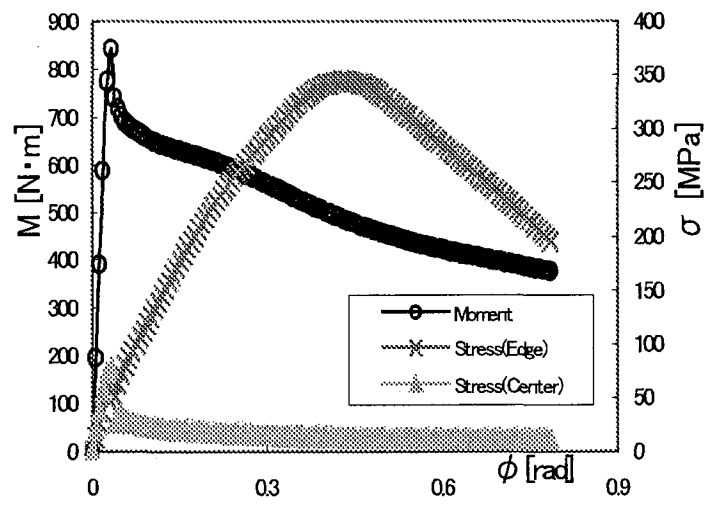

Fig. 8 Variations of bending moment and stresses with rotational angle for model $\mathrm{B}$.

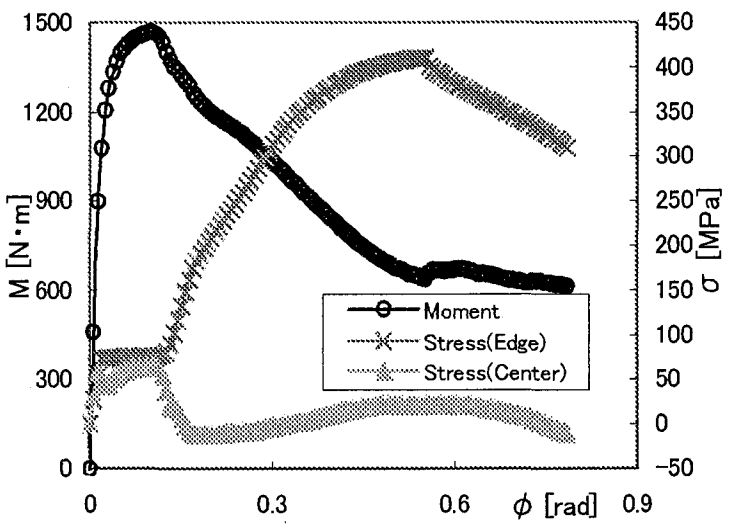

Fig. 9 Variations of bending moment and stresses with rotational angle for model $\mathrm{C}$. 